\title{
Roman SZUL* \\ GEOPOLITICS OF NATURAL GAS SUPPLY IN EUROPE - POLAND BETWEEN THE EU AND RUSSIA
}

\begin{abstract}
The article analyses possible interests, attitudes and activities of the major actors in the 'natural gas supply game' in Europe after 1990: Russia/Gazprom, alternative suppliers like countries in the Caspian Sea area, the main consumers of gas and transit countries. It stresses that behaviour of the actors depends on the changing international political and economic situation and conditions in individual countries. Special attention is paid to pipeline projects: Nord Stream, South Stream and Nabucco, and reactions to them, such as building a LGN terminal at Świnoujście (Poland), North-South (Baltic-Adriatic) energy corridor and the Polish-Russian gas contract of 2010.
\end{abstract}

Key words: natural gas resources, geopolitics, Europe, Russia.

\section{INTRODUCTORY REMARKS}

International energy trading is one of the major political issues in contemporary Europe. At stake are energy security of energy importers and consumers, big profits of energy producers and exporters and of firms related to this activity as well as possible political influences exerted by national governments and international institutions like the EU. Given technological characteristics of natural gas industry and trading: lack of conditions for 'normal' competition, high dependence on pipelines as the way of transportation (and thus on governmental decisions on their routes), big amounts of capital for investments in exploitation of new fields and in transportation and in other infrastructure (e.g. in terminals for importing LNG), etc. This sector is especially dependent on

* Roman SZUL, University of Warsaw, Centre for European Regional and Local Studies, Warsaw, Poland, e-mail: r.szul@chello.pl. 
governments and thus politicised. The pressure for 'clean energy' and reducetion of emission of air pollutants in Europe even more strengthens the importance of natural gas as a source of primary energy and makes its supply a more political issue.

The intertwining and interplay of money and politics, in other words, of economic, technological and political considerations, makes the game of international gas trading very unclear. What is especially unclear are long term intentions of some players. A special source of lack of transparency in this issue are the changing political relations between the major players resulting from developments in activities not related directly to energy trading, such as the Russian-Georgian war in 2008, the 'orange revolution' in Ukraine in 2004/2005 and the resulting worsening of political relations between Russia and some EU members (first of all Poland), and then the improvement of Polish-Russian relations in 2009 and 2010, etc. This changing political climate influences the way of perceiving intentions of individual participants of the game by their counter partners. Economic instability (e.g. the economic crisis in 2008/2009 resulting in declining demand in major European markets) and technological changes (e.g. increase in shale gas production in the USA in 2010 leading to a drop in price for NLG world-wide) add to the instability and complexity of the gas trading business.

In sum, international gas supply in Europe has become a really geopolitical game. This article tries to outline some crucial elements in this game. The focus is the situation in Poland against the broader background of relations between Russia as the main supplier and European countries as consumers of natural gas, and the European Union as a rule-setter in the gas trading industry. The paper concentrates on developments after 2000 , with only a short comment on the previous situation.

\section{THE MAIN PLAYERS AND RULES OF THE GAME}

To describe any game it is necessary to present its participants (players) and rules of the game. In the geopolitical game for gas trading in Europe it is rather difficult to single out the players and to determine rules of the game as these are also the subject of the game.

What concerns the players, the problem is especially Russia and the relationships between its government (in a broader sense including both 'Kremlin' and the government proper) and Gazprom: to what extent Gazprom is economic instrument in geopolitical games of its main shareholder, i.e. the Russian government, or vice versa, to what extent the Russian government acts as 'political arm' of Gazprom promoting its economic interests internationally. 
Given the activities of the government and of Gazprom in recent years, several interpretations are possible, and the choice of interpretation to a large extent depends on political attitude towards Russia: those who perceive Russia as a reliable partner tend to consider Gazprom as a 'normal' business company pursuing economic goals and interested in its reputation as reliable trading partner, ${ }^{1}$ while those who are afraid of Russia's imperialist tendencies see expansion of Gazprom as a tool in Russia's foreign neo-imperialist policy. ${ }^{2}$ For instance, interruptions in gas supplies to Belarus and Ukraine by Gazprom/Russia could be interpreted as an economic decision of Gazprom motivated by the necessity to force partners to pay for deliveries (economic interpretation) or as an element in political games of Russia to force these countries to political concessions for Russia (political interpretation).

\footnotetext{
${ }^{1}$ Such an opinion is presented by several German politicians, experts and businessmen (see as an example opinion of German expert Roland Götz: 'Moskau nutzt seine Energie nicht als Waffe' [Moscow does not use its energy as weapon]; 'Moskau nutzt...', 2009). A similar opinion is expressed by Bernhard Reutersberg, Head of E-ON Ruhrgas in an interview for Süddeutsche Zeitung: 'Russland ist ein zuverlässiger Partner' [Russia is a reliable partner]; 'Russland ist...', 2009). According to them, Russia is a reliable supplier of energy to Germany and Europe and never uses energy as a political weapon: it supplied gas to (West) Germany during the cold war, perestoika, collapse of the USSR, times of Yeltsin and Putin. Problems (interruptions in supply of Russian gas to Europe in recent years) were due exclusively to others - to the transit countries, mainly to Ukraine which did not pay in time for Russian gas and/or was stealing it. According to this opinion, Gazprom, although owned mostly by the Russian state, is an independent commercial company behaving as a commercial firm in line with wishes of (minority) private - including foreign - shareholders. Gazprom does not want and can not use energy supply as political weapon, e.g. by stopping supplies or threatening to stop them because it would damage its main asset reputation. This expert is consequent in denying existence of political game played by Russia in the area of gas exports - when asked by journalist about Russia's attempt to create a 'gas OPEC' with such countries as Venezuela, Iran and Qatar, he downplays these attempts as only a meaningless psychological pressure. Accordingly, harmful political game is played by those who hinder realisation of Russian projects of Nord Stream and South Stream and force unrealistic alternative projects as Nabucco which introduce unnecessary mistrust in the fruitful RussianEuropean cooperation.

${ }^{2}$ This opinion is best represented by Hungarian Tamás Varga (2008). His article relates to Nord Stream. According to the author, the idea of building a pipeline directly connecting Russia and Germany and bypassing Poland and the Baltic countries has a strictly political significance. It is element in Russia's long term and large scale political strategy. Its main aim is to make Germany dependent on Russia (on Russian energy supply and on profits resulting to Germany from its role as distribution centre of Russian gas in Europe) and thus to make Germany Russia's ally or assistant, and, at the same time, to 'draw' Germany out of the European Union and thus to 'neutralise' the EU as a political player. A secondary aim, fully compatible with the main one, is to weaken Poland and the Baltic countries by making them vulnerable to Russian energy blackmail (by possible turning off supply of natural gas to them in existing pipelines without affecting supplies to Russia's main partner - Germany). According to this reasoning, it is up to Germany to accept the role of Russia's strategic assistant and 'neutraliser' of Europe and Russia's partner in weakening and blackmailing Poland and other countries between Germany and Russia.
} 
Anyway, the government of Russia and Gazprom are very important, sometimes and for some even the most important player(s). Regardless of the relationships between the Russian government and Gazprom, their short and medium term interests seem to be common: preserving or strengthening their position as a major supplier of gas for European countries, if possible by obtaining (preserving) their monopolistic position on the European gas market, reducing dependence on transit countries (by direct connections with each partner country) and thus imposing as high prices as possible. Controlling gas pipelines from Russia to final consumers is also in their interest. These common interests enable both Gazprom to gain high profits and the Russian government to exert political influence on European countries.

Other players are governments of Western European countries, first of all of Germany, France and Italy, as importers of gas from Russia and from elsewhere. Given that imports from Russia is only a part of their gas consumption (not exceeding $25 \%$, and even less in their total energy consumption), these countries do not feel being dependent on Russian supplies and are not afraid of (some) increase in imports from Russia. They are strongly pushed for cooperation with Russia by their firms (so called national champions), both from the energy sector and others, interested in doing business in Russia. As a result, these governments are ready for cooperation with Russia even while neglecting opinions of those countries (including other members of the EU) who may object such a cooperation.

Between Russia and Western Europe are countries of Central and Eastern Europe, including Poland. They are both importers and transit countries for Russian gas exports. As importers they are highly dependent on Russian gas. Therefore they are interested in reducing this dependence, among other things by having access to alternative sources of supply, such as imports from the Caspian Sea area, imports of LNG, etc. As transit countries they are interested in retaining this position, both for economic and political reasons. Poland being on the gas pipeline route form Russia to its major customer - Germany hopes that Russia would not 'turn off' gas supply to Poland because this way it would harm Germany.

The difference between some Central European countries (like Poland, Lithuania, Latvia and Estonia) and Western European countries in their attitudes towards Russia results also from their history dating back to the times of Russian empire. Therefore the former countries are more inclined than the latter ones to interpret Russian decisions as elements of the geopolitical game aimed at restoring the empire. ${ }^{3}$

\footnotetext{
${ }^{3}$ German analysts Florian Baumann and Georg Simmerl describe in detail differences between EU member states resulting from different energy mixes, different dependence on energy imports, different geographical sources of imports, different geographical location, role of state and market in energy business, etc. In their opinion, these differences create 'path dependency' determining, for instance, different attitudes to cooperation with Russia (see Baumann and Simmerl, 2011).
} 
Of special importance as consumers of Russian gas and transit countries are Belarus and Ukraine. Their role in the geopolitical game of gas supply is a part of their larger and very complicated political and economic relations with Russia, highly dependent on volatile attitude towards Russia, towards their own political and economic independence, etc. Generally, they are interested in retaining their position as transit countries and in getting economic concessions from Russia including reduced prices for Russian gas, if necessary by granting Russia political concessions. ${ }^{4}$

A special position is taken by the three Northern Baltic countries - Finland, Sweden and Denmark - as potential transit countries (for the pipeline on the Baltic seabed). Sweden differs from the other two as not being interested in imports of Russian gas and being less politically dependent on Russia than, for instance, Finland. All the three are interested in preserving natural environment, including that of the Baltic Sea, and, at the same time, their firms and local governments would not reject contracts with Gazprom in building pipelines and fees for exploitation of the pipelines.

As mentioned earlier, some European countries (and EU institutions) would like to diversify sources of gas supply by importing gas from the Caspian Sea area. This makes gas producing countries of this area, in first instance Azerbaijan, then Turkmenistan and, possibly, Iran as well as the transit countries Georgia and Turkey - players in the game. As regards Azerbaijan and Turkmenistan, they are interested in getting access also to other markets than Russia. For the former it is primarily Europe, for the latter it is China. Russia, in turn, would like to take (retain) control of the Caspian gas by importing it from Azerbaijan and only then to re-export it to Europe. Azerbaijan does not reject Russian competition for its gas as it raises prices but it must not eliminate direct contact with European partners, otherwise it would be totally dependent on Russia as importer and/or transit country.

Georgia and Turkey try to make use of their transit position in their economic and political bargaining with Europe and the West in general. For the present pro-Western leadership of Georgia this role is a way of securing Western support for Georgia's ambitions to join the West.

Norway being a gas exporter to Europe is another player in the game. Its position strengthens after the recent enlargement of its territory in the Arctic Sea with possible new gas deposits. As a producer, Norway can be to some extent an alternative to Russia.

Not negligible is the intentional and unintentional role of the United States in the European geopolitical gas game. The unintentional role consists in influencing the global gas market. It can be seen in the recent declining prices of LNG as

\footnotetext{
${ }^{4}$ On complicated relations between Russia and other post-Soviet countries in gas industry see Wyciszkiewicz (2008).
} 
the result of exploitation of shale gas in the USA and the related reduced global demand for LNG. The intentional role of the USA is its political support for Georgia. Activity of American firms in searching for shale gas, for instance in Poland, is also worth mentioning.

The last but not least player in the game is the European Union, and especially the European Commission. The European Commission plays a double role - as a regulator of the gas industry in the European Union and as (potential or actual) participant in projects, first of all in building infrastructure. Given the nature of the EU and the composition of the European Commission, it is not clear to what extent the Commission is an independent player and to what extent it represents interests of the most influential EU members. It is worth mentioning that in the present Commission the commissioner for energy is a German national. Nevertheless, the Commission seems to pursue three objectives in the gas game: (1) increasing supply (imports) of gas from outside the EU, (2) encouraging competition in the European gas market by regulations preventing monopolies of supply, (3) enhancing energy security by integrating transport (pipelines) infrastructure. Apart from the European Commission the European Parliament should also be noted as a place where various political opinions are presented and thus influencing political climate in the EU.

While participants of the game are more or less discernible, rules of the game are less clear. As mentioned earlier the main source of uncertainty is Russia and its intentions, when it became assertive after 2000. Uncertainty about Russia's intentions and possibilities to fulfil them makes that there are various and changing interpretations of Russian intentions and attitudes towards Russia among European countries, and among individual politicians, businesspersons and experts.

Several propositions as to Russian intentions can be developed:

1. Russia as a global superpower engaging Europe's potential. According to this proposition, Russia aims at (re)gaining the position of a global superpower, equal to the still powerful America and the rising China (and other possible global players). To do so Russia needs to harness Europe's economic, technological, demographic and cultural ('soft power') potential to serve Russian global political interests, while marginalising Europe politically and preventing it from being another global player. Therefore Russia tends to disunite the European Union by picking out 'good' and 'bad' boys. 'Good boys' - countries, firms, individual politicians, etc. who can be useful and are ready to be useful in the Russian strategy are offered (bought by) economic rewards - contracts, positions in Russian-controlled companies, etc. A special role in this strategy is ascribed to Germany due to its potential and its position in the EU (the UE without Germany can not be a superpower). Making Germany dependent on Russia is therefore of paramount importance. The best, if not the only, way to make Germany dependent on Russia is to offer Germany and German firms and 
individuals lucrative contracts and positions, first of all in energy industry (Russia has few alternatives outside this sector). The direct gas pipeline from Russia to Germany on the Baltic seabed (bypassing transit countries and making Germany 'distribution centre' or 'hub' of Russian gas in Europe) and the related contracts and positions are in line with this strategy. 'Bad boys' - countries which oppose this strategy are punished (by not offering advantageous conditions in mutual trade, by bans on their exports to Russia for 'sanitary reasons', if necessary by 'turning off' the gas tap, etc.). Gas pipelines bypassing the 'bad boys' can be useful in blackmailing and punishing such countries. Productive in this way of policy is also isolating and marginalising the 'bad boys' in Europe by presenting them (directly or via friendly or hired 'good boys') as irresponsible Russophobes, short-sighted nationalists, etc. Instrumental in this strategy is also preventing Europe from access to alternative (non-Russian) sources of imports of gas, for instance from the Caspian Sea area.

2. Russia-Europe strategic partnership. The difference between this strategy and the previous one is that Russia admits active political role of Europe as its partner and strategic ally. Consequently, it is less interested in disuniting Europe, in rewarding some and punishing other countries, in preventing Europe from access to the non-Russian sources of energy. The key problem here is to persuade Europe to be Russia's, and not America's, let alone China's, strategic ally. Offering advantageous cooperation to European countries and firms, according to their economic and technological capacity rather than according to 'divide and rule' political considerations, makes this goal more possible.

3. Regaining the Soviet empire. Russia is interested first and foremost in regaining (or retaining) political and economic control over former Soviet republics (possibly except the three Baltic countries already in the EU and NATO), first of all over Belarus and Ukraine by preventing their access to the Western zone of influence, mainly to NATO. Russia's policies towards the rest of Europe is only a side effect of this strategy. For instance, the main aim of the gas pipelines on the Baltic seabed ('Nord Stream') and on the Black seabed ('South Stream') is to bypass Belarus and Ukraine respectively, and thus to exert pressure on these countries. That these pipelines bypass Poland or other countries of Central and Eastern Europe is only a matter of geography. Russian military, political and economic activity in the area of Caucasus (including the Russian-Georgian war of 2008) is only a result of Russian attempts to secure its vulnerable southern regions, to stop Islamist Chechen terrorism and to defend Russian citizens in this area, and is a defensive response to provocations by others (Chechen rebels, Georgian government, etc.). While trying to regain/retain its control over its 'near abroad' Russia is all the time interested in retaining mutually beneficial relations with European countries.

4. Changing or non-existing long term political goals. According to this interpretation, Russia does not pursue a coherent well defined long term foreign 
policy. This policy is the resultant of changing mood and attitudes of political and military leaders, pushed by nationalistic and anti-Western sentiments among Russians, tending to restore Russian political might globally or, at least, pretending to do so, and interests of the powerful 'oligarchs' desiring to continue advantageous commercial relations with the West. As regards the latter factor, it is worth underlining that the oligarchs keep in the West their most valuable assets: their children (most children of oligarchs study in Western European countries or America, or simply live there), their property (including expensive houses and villas in fashionable resorts) and money (in bank accounts). Therefore the last thing they strive to is to break economic cooperation between Russia and the West or to worsen Russia - the West political relations to the point that the oligarchs can not continue their way of life and doing business (selling Russian raw materials to the West and enjoying living, buying and spending holidays in the West and sending there their children). While interested in doing business with the outside world, Russian oligarchs (and other businesspeople) tend to create and exploit all opportunities to force their foreign partners to accept less favourable conditions, for instance higher prices for Russian exports, lower fees for exploiting foreign infrastructure by Russian firms, higher shares for the Russian partners in joint ventures, etc. Instrumental in such a behaviour of Russian businesspeople is, among other things, avoiding (bypassing) intermediaries and transit countries and making use of their monopolistic position by imposing higher prices to their customers. There is a notable exception to this behaviour: it is Belarus and Ukraine where political considerations (low, politically determined prices) compete with economic consideration (high, world market prices). The resultant of political and economic interests depends to a large extent on the economic situation in Russia and abroad, first of all on energy prices and revenues. In times of rising prices of oil and gas, rising revenues of the Russian budget and rising profits of Russian firms, Russia is more inclined to pursue the neo-imperialist global policy, while in times of declining prices and revenues Russia is better disposed to see its limitations and tends to cooperation with the West, including Europe.

The choice of interpretation of Russian intentions depends on geopolitical and economic situation, and historical experiences of individual countries, on political attitudes of persons concerned as well as on the general international political climate.

In comparison with unclear rules of the game played by Russia, the 'gas game' played by European countries and the EU seems to be clear and simple: getting access to Russian gas supplies while avoiding excessive dependence on them, and profiting from other forms of cooperation with Russian gas industry. In other words, it is an economic game. Politics here is in reactions to Russian initiatives. 
From the point of view of the broader political and economic context in which the geopolitical gas game between Russia and Europe takes place, the period after 1989/1991 (when the game really began) can be divided into three stages:

1. 1989/1991-2000. Weak and confused Russia, relatively strong Western Europe. In this period Russia underwent political, economic and ideological crisis. Dramatically declining living conditions of the Russian population, growing external indebtedness of the Russian government, collapse of the socialist economic and political system and attempts to introduce Westernstyle economy and democracy, inexperience of the emerging entrepreneurial class all that made Russia highly dependent on the West, including Western European countries, as sources of investment capital, credits and advice. For the affluent, stable West, Russia was an area of political instability that eventually could affect the West, and an area of great opportunities, including as location of natural deposits to be exploited by Western firms. The West was relatively united and self-confident after the end of the cold war and collapse of communism.

2. 2000-mid-2008. Growing assertiveness of Russia, growing prices of energy on international markets, confused Europe. The political and economic consolidation of Russia under the new leader - Vladimir Putin, growing prices of energy and the resulting growing revenues of the Russian budget and rising incomes of Russian 'oligarchs', paying off external debt and accumulation of a huge amount of foreign currency reserves, all that made that both the Russian leadership and business became more assertive in relation with Europe (and the rest of the world) and felt they could carry out an active long term policy (that some called 'neo-imperialist' or 'divide and rule') towards Europe. At the same time Europe, scared by the growing prices of imported energy and insecurity in the Middle East, disunited in its attitudes towards the USA (for its wars in Iraq and Afghanistan and reluctance to accept 'European values'), confused by the enlargement of the EU (in 2004 and 2007) and lacking sense of common goal became the weaker player of the geopolitical gas game with Russia. Different approaches to Russia appeared among governments, politicians and experts, even within one country. While some saw Russia as a counterweight for the adventurous USA and a reliable economic partner, others, mostly in Central and Eastern Europe, but also in Western Europe, were afraid of the new assertiveness of Russia and its policy to use energy as a political instrument, and were disappointed for Russian neglect for principles of democracy, state of law, freedom of speech, etc.

3. Since mid-2008 until now (beginning of 2011). Less self-confident Russia, more suspicious Europe, both hit the economic crisis. Declining price of energy since mid-2008 and the economic crisis of 2008-2009 reduced Russian capacity 
to carry out assertive foreign policy towards Europe, the crisis itself revealed interdependence of Russia and Europe and pushed Russia to cooperate with Europe rather than to divide it and reward some and punish other countries. The growing power of China also made Russia looking for tighter relations ('strategic partnership') with Europe. On the other hand the Russian-Georgian war in August 2008, recognition by Russia of the break-away regions of Georgia (Abkhasia and South Osetia) as well as the prolonged gas conflict of Russia with Ukraine at the beginning of 2009 (switching off Russian gas supply to Ukraine and further to other countries) all strengthened suspicions in Europe as to Russian intentions and made arguments of the 'Russia-sceptics' in Europe more acceptable. It seems that also Russian society and leadership are undergoing a mental transformation from acceptation of authoritarian rule in exchange for stability and growing well-being towards a more open, democratic and 'modern' society. In this context Europe is becoming, again, attractive for Russia.

Behaviour of individual countries in the geopolitical game depended not only on the above described general framework, but also on country-specific characteristics. In the case of Poland these characteristics consisted, first of all, in its attitudes towards the EU, Russia and Ukraine. Since the outbreak of the USSR (or even before it) Poland supported independence of Ukraine and its democracy considering it as a barrier to re-emergence or expansion Russian imperialism and autocracy. This attitude was especially evident during the socalled orange revolution in Ukraine in 2004/2005. Polish support for Ukraine and opposition to the growing influence of Russia in Europe irritated Russia and was only half-heartedly backed, if not ignored, by West European countries. This situation directly influenced positions of all parties in the gas game (see below). Possibilities of Poland to influence EU's stance towards Russia and Ukraine were especially reduced in 2005-2007 when Euro-sceptic antiRussian and strongly pro-American right-wing parties were in power. The situation changed after parliamentary election in Poland in 2007, presidential election in Poland in 2010, the change of power in Ukraine and the US-Russia 'reset' by president Obama. In Poland the power was overtaken by proEuropean and more pragmatic in relation to Russia and Ukraine parties. The change of power in Ukraine in favour of the pro-Russian party was regarded in Poland as the final loss of Ukraine and was received by some in the government with relief as opening up new prospects for cooperation with Russia. Russian leadership also seems to make use of the new situation by improving its relations with Poland, maybe in order to improve its image in Europe or recognising Poland's strengthened role in the EU. This new Russian attitude towards Poland manifests itself, however, in symbolical gestures, without direct effect on economy, including the gas game. 


\section{ACTIONS AND REACTIONS}

Below are presented some initiatives in the geopolitical gas game between Europe and Russia, with special reference to Poland (see figure 1).

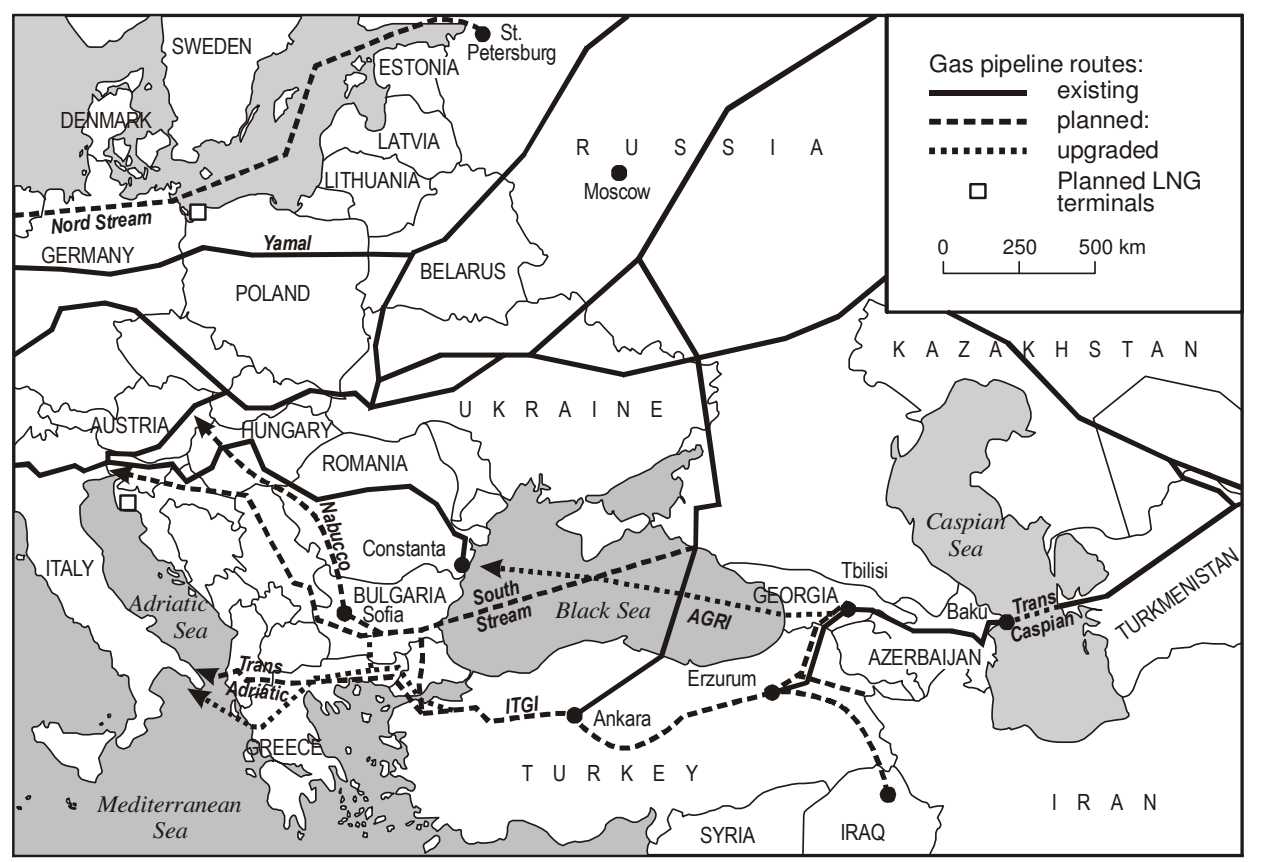

Fig.1. The main existing and planned gas pipelines and LGN terminals in Central and Eastern Europe, Russia and the Caspian Sea area

Yamal I gas pipeline from Russia via Belarus, Poland to Germany proposed and built in the 1990s. This was a result of the growing demand for gas, especially in Germany, and of the necessity for Russia to increase its gas exports to earn much needed hard currency. The route of the pipeline was mostly determined by economic and technical factors as it was the shortest possible and easiest to build route from Yamal peninsula (north of the European part of Russia) to Poland and Germany. It had also some political significance as it diminished dependence of Russian export of gas to Europe on pipelines leading through Ukraine, and further through Slovakia, and then westwards to the Czech Republic, Austria to Germany or southwards to the Balkans. This dependence on the Ukrainian-Slovakian corridor bypassing Poland was, in turn, the result of mistrust of Russia to Poland as an unreliable partner in the socialist block in the 1980s. (It should be added that before building Yamal I Poland imported gas from the USSR by some small pipelines crossing the Polish-Soviet border). 
In the 1990s Polish and Russian governments also agreed upon building $Y a$ mal II pipeline, but it never started. At the beginning of the next decade, in a new political situation, Russia proposed that Yamal II cross the ByelorussianPolish border, then go along the Polish-Ukrainian border to eastern Slovakia where it should join the existing pipeline connecting Russia with Central and Western Europe. In such a way Yamal II would have bypassed Ukraine. Polish government rejected this proposal arguing that there is no sufficient demand for gas in south-eastern border areas of Poland and that the building of the pipeline would be harmful for the there rich natural environment. Instead, Poland suggested that the route of the pipeline should go more to the west, through more industrialised and urbanised areas of south-central Poland. This was, in turn, rejected by the Russian side. An unofficial, but very important reason for the Polish government to reject the original Russian proposal was that it was too much provocatively and ostensibly anti-Ukrainian and that its political aim was to demonstrate that Poland relinquished Ukraine, its strategic partner, and joined Russia. The rejection of the Russian side of building the pipeline in an area more distant to the Polish-Ukrainian border confirmed Polish suspicion that the aim of the proposal was to provoke a conflict between Poland and Ukraine.

Nord Steam pipeline connecting Russia with Germany under the Baltic Sea. It was agreed by Russian and German governments in 2005. It is theoretically an undertaking of commercial firms: Gazprom (majority shareholders with 51\% of shares), and German firms E-ON Ruhrgas and BASF (jointly $49 \%$ of shares). Later on Dutch firm Gasunie was admitted with $9 \%$ shares conceded by the German firms (which now possess 20\% each), and France (EdF) also joint the project. The pipeline will connect Russian Vyborg (near St. Petersburg) with German town Lubmin (near Greifswald) a few kilometers west of the GermanPolish border. Then, it would be divided into two lines: one (called 'Opal') leading southwards along the German-Polish border to the Czech Republic, and the other westwards to the Netherlands, and possibly further. Construction works officially started in April 2010, but production and storing of pipes began earlier. Now, in February 2011, construction of the Nord Steam is under way.

The idea of Nord Stream emerged in a specific economic and political atmosphere of the first decade of the 21st century: growing prices of energy (oil and gas) and perspectives of even greater increase in prices and demand for gas, strengthening Russian assertiveness, tensions between the USA and the main Western European countries (first of all Germany and France) resulting in creation of the Paris-Berlin-Moscow axis and plans to build a gas pipeline from the Caspian Sea area to central Europe bypassing Russia called Nabucco (see below). The Nord Stream project can be subject to various interpretations. First, as a commercial undertaking connecting directly the supplier with its main customer bypassing transit countries (in this case Belarus, Poland and Ukraine) and making gas deliveries independent on the situation in these countries. 
Although the short term costs of building this line is higher than costs of a possible alternative (on the land, along the Yamal I pipeline through Belarus and Poland) long term benefits for the two parties concerned would compensate for the initial expenses. The weakening of the position of the transit countries is only a side-effect and not a deliberate aim of the project. A second interpretation is that the aim, apart from directly connecting Russia with Germany, is to weaken the position of Belarus in its relations with Russia. It should be taken into account that these relations were quite tense and there were frequent conflicts between the two countries over prices of gas, fees for transportation of Russian gas via Belarus, overtaking of Byelorussian pipelines and other objects by Russian firms, etc. A more radical and political interpretation is that it is element of the Russian neo-imperialist strategy and German consent to play the role of Russia's main ally in this strategy.

The two parties - Russia and Germany - officially declare that it is a commercial undertaking, not aimed at harming any third party, although in analysis of the project presented to the broad public opinion its negative impact on third countries is usually ignored. Germany also invites Poland to build an intercomnector from Germany to Poland, in order to export gas to Poland, and to make this undertaking economically viable.

The European Union approved the project as securing additional imports of gas to the UE.

The idea of building a pipeline under the Baltic Sea raised concerns of governments and protests of environmentalists in northern Baltic countries (Finland, Sweden and Denmark). (The pipeline bypasses territorial waters and economic zones of the southern Baltic countries: Estonia. Latvia, Lithuania and Poland). The most suspicious towards the pipeline was Sweden, which, unlike Finland and Denmark, could not be persuaded by deliveries of gas from the pipeline as Sweden did not need Russian gas. Finally, however, all the three countries gave their approval to the project. It should be mentioned that, for instance, Swedish firms and local governments are engaged in the project (e.g. by transporting and storing the pipes on their territories) and their fishermen are offered substantial compensation for the lost income during the construction works, and local governments will benefit from transportation fees.

The Nord Stream project provoked negative reactions in Poland and the three Baltic states. It was interpreted as an attempt to circumvent these countries, to weaken them by giving Russia possibility to blackmail them by turning off gas supply without doing harm to Germany-Russia's strategic partner. To Poles the route of the pipeline - on the bottom of the sea bypassing Poland and then along the German-Polish border - resembled very much the Russian proposal of Yamal II. As the Yamal II was interpreted as a Russian attempt to drive a wedge between Poland and Ukraine and to demonstrate Poland's neglect for Ukraine, Nord Stream was interpreted as a (successful) attempt to drive a wedge between 
Germany and Poland and to demonstrate that Germany neglected Poland. It also revoked historical memories of anti-Polish German-Russian plots in the 18th and 20th century (e.g. the ill-famous Ribbentrop-Molotov treaty of 1939). Absence of any consultation with Poland-Germany's partner in the EU and NATO - was also striking and significant. For the new Polish political elite Nord Stream became a lesson of Realpolitik and rules of the game in the EU.

Polish authorities since 2005, despite changes of persons in the office of prime minister and president of the republic, let alone ministers, invariably criticize Nord Stream and undertake or consider some reactions. In this regard three kinds of ideas can be mentioned: (1) looking for additional, non-Russian, supplies of gas, (2) persuading the EU to stop building Nord Stream, or to soften its possible negative impact on Poland by introducing solidarity emergency mechanism of energy deliveries to countries affected by interruptions in deliveries and/or to introduce other mechanisms in the EU safeguarding interests of gas importing countries, (3) ensuring functioning of the Yamal pipeline.

Among ideas of diversifying sources of gas imports were the recurrent idea of importing gas from Norway by a pipeline that should be built between Scandinavia and Poland. This proposal, analysed in early 1990s and then after the Nord Steam, was finally scrapped as economically not viable (too small demand to build a pipeline). Another idea is to import LNG. To do so Polish government decided in 2006 to build an LNG terminal. Its location in Świnoujście Port was determined later, and a contract with Qatar for deliveries of LNG after the terminal is completed was concluded in 2009. Then the preparation for realisation of this project accelerated. The construction of the terminal encounters some problems that deserves comments. Świnoujście is located in extreme north-west of Poland not far from Szczecin and a few kilometers from the Polish-German border, and what is especially important, a section of the fairway leading to the port is on German territorial waters, in the area where the Nord Stream pipeline will be put. According to the construction project of Nord Stream, the pipeline will be put just on the sea bottom thus hindering access of bigger ships, such as LNG tankers, to the port. Despite appeals of the Polish authorities to the German government and to the Nord Stream company to dig in the pipes into the sea bottom so that they not block the access to the port, the problem until now has not been solved. It seems that German response to Polish request in this matter will be a test of German intentions and of its attitudes to Poland, and of Poland's ability to defend its vital interests vis-à-vis Germany. ${ }^{5}$

\footnotetext{
${ }^{5}$ Needless to say, that Polish experts often express opinion that the German obstinacy is not an accident, but a deliberate action to derail the project. Some experts also hint that the choice of Świnoujście was not only not the best one (a better option was port of Gdynia-Gdańsk) but also that consulting firms responsible for selection of the location were also engaged in Russia and Germany, so they in fact served interests of these countries when choosing Świnoujście which can be blocked by Germany. See e.g. 'Dlaczego Niemcy...', 2010 (in Polish).
} 
The LNG terminal at Świnoujście is to be element of a broader international project called 'North-South gas corridor' entailing another LNG terminal in Croatian island of Krk and a network of pipelines between Poland and Croatia in Central Europe (Austria, the Czech Republic, Slovakia, Hungary, Slovenia, and Romania besides of Poland and Croatia), for which some interconnectors have already been built and others should be built in the near future. To fulfil this idea Poland is active in the EU (which otherwise supports building interconnectors as an element of creation of the European energy market) and in the Central European region (for instance, in the Visegrad Group, an intergovernmental consultative body established in early 1990s by Poland, the then Czechoslovakia and Hungary, now a lobby group in the EU). ${ }^{6}$

Despite its backing for interconnectors, Polish government so far rejects the German proposal of building a pipeline from Opal pipeline to Szczecin, and thus to export Nord Stream gas to Poland. Accepting this proposal would mean accepting the idea of Nord Stream and of the position of Poland as an end-ofpipe receiver which Poland tries to avoid. Importing Russian gas via Germany from Nord Stream would undermine viability of Polish LNG.

Another possible source of natural gas for Poland is shale and tight gas, and in 2010 Poland gave several (altogether 70, including mixed concessions - for shale/tight and conventional gas) concessions, mostly to American firms, for exploration and exploitation of shale gas ('70 koncesji ...', 2010).

In the European Union (European Commission, European Parliament, etc.) Poland (the government, Polish MEPs of various orientations) tried to persuade the EU to stop Nord Stream or at least to demonstrate that the true motives behind this project were far from just supplying gas to Europe, and that it does not serve European interests. To do so Poland, together with the three Baltic states, planned to submit an alternative pipeline project called 'Amber' leading from St. Petersburg (in the point where Nord Stream starts) via the Baltic countries and Poland to Germany. The aim of submitting this proposal was to force the EU to compare the two projects and thus to draw the conclusion that Nord Stream was economically, technically and environmentally worse. The Amber project was, however, not presented officially to the EC because Latvia, in the last moment, withdrew its support, probably not without pressure from the pro-Nord Stream lobby. (One of ways of acting of this lobby is offering high positions in the Nord Stream corporation, as in the case of the former German chancellor Schröder who as chancellor concluded the agreement with Putin and who shortly afterwards became president of Nord Stream AG).

The Polish (and Baltic) campaign to stop Nord Stream in the EU failed, but the suspicion as to intentions of the Nord Stream proponents and to the role of

\footnotetext{
${ }^{6}$ For more on the North-South corridor project see Kublik (2011).
} 
Russia and Germany in Europe remained. ${ }^{7}$ Maybe Russian leader drew the conclusion that Poland should not be completely ignored and Russian symbolical gestures to improve relations with Poland after 2008 are a result of such a conclusion. At the same time German leaders may have concluded that energy matters in the EU should not be left to accidental persons in the Commission and proposed their candidate - Günther Öttinger - as commissioner for energy in the new EC that took office in 2009.

Another way of Poland's action in the EU was to strengthen the solidarity emergency mechanism of gas supplies. Despite opposition of such countries like Germany and the UK arguing that such a mechanism would distort the functioning of the gas market (and not feeling a threat of switching off of gas supplies form Russia or elsewhere), ${ }^{8}$ Poland and other countries managed to introduce the idea of energy solidarity to the Lisbon Treaty. This success is, however, incomplete, as there are various interpretations of this idea, and there are several technical details that should be cleared, as well as technological conditions (interconnectors!) must be met to make the idea working.

\footnotetext{
${ }^{7}$ See for instance opinions expressed by Dieter Helm (2007), professor of energy policy, Oxford University. When analysing motives of Russian energy policy he underlines: 'Its [Russia's] interests are to maximise the economic and political leverage of its energy assets, and this is a reality that the EU needs to come to terms with - rather than continue to imagine that Russia will adopt an open third-party access regime to its gas pipes and open up its oil and gas reserves to all comers' (p. 2). Describing president Putin's background as an important factor of Russia's policy the author adds: 'He developed an affinity to Germany in the process, which has helped in shaping the "special relationship" with Germany, and the attempts to use Germany to drive a wedge between Poland and the Baltic States, on the one hand, and Germany, on the other' (p. 20). He also denounces attitudes of Germany and France in their dealing with Russia in energy industry, especially the Nord Stream pipeline, as detrimental for European interests: 'The reluctance of member governments to allow a similar role for the EU [as in the case of Kyoto protocol, reduction of $\mathrm{CO}_{2}$ emissions, etc.] in security of supply matters has already had real costs to the $\mathrm{EU}$, and the choice is now between the national interests of the dominant countries - particularly Germany and France - and the wider EU interests' (p. 2), 'in the case of energy the fear in other European countries is that Germany's national interests in energy are rather different from those of Europe as a whole, and the bilateral relationships which Germany has been pursuing with Russia are at the expense of the European wider interests. Of all the manifestations of this tension, the Baltic Pipeline is the most obvious example' (p. 35). 'The Baltic Pipeline not only increases Russian power in respect of Ukraine, but it also serves to remind Poland and the Baltic states of their historically somewhat precarious position sandwiched between Russia and Germany. [...] Unsurprisingly, then, there is suspicion that the Baltic Pipeline is a German-Russian enterprise, rather than a European-Russian, and a divisive rather than inclusive step' (p. 36). 'As noted above, the Russian strategy has been to pursue bilateral agreements with individual EU member states, against the backdrop of "special relationships" with Germany. In this, it has been largely successful. Germany is the Russian hub, with all the strategic, industrial and security benefits that follows' (p. 52).

${ }^{8}$ On the controversy about solidarity mechanisms in cases of energy supply interruptions see Baumann and Simmerl (2011, p. 20).
} 
As mentioned earlier, Poland supports EU initiatives aiming at liberalisation of the EU energy (in this gas market). One of instruments of this policy is the so called 'unbundling' - separation of the function of pipeline ownership and pipeline operation. According to the EU 'third energy packet' approved in 2009 (to come in force in March 2011) pipeline owners must let independent pipeline operators current maintenance and administration, including admitting third parties to the pipeline so that there can be competition between gas suppliers. This mechanism should prevent monopolies and thus rising prices and blackmailing customers. Therefore, it defends such countries like Poland from abuses of monopolist suppliers.

Polish support for the unbundling, however, turned out to be in contradiction with Poland's aim to ensure functioning of the Yamal pipeline and securing Russian supplies. In 2010, in September, Polish-Russian contract on gas supplies expired. Before that Poland and Russia had to conclude a new contract. PolishRussian negotiations were protracted and difficult (especially for the Polish part). The disputed questions were amounts of gas to be sold to Poland, prices for gas, fees for gas transit in Poland (and other issues related to the EuRoPol - a Russian-Polish company transporting Russian gas though Poland), time of duration of the contract and conditions of functioning of the Yamal pipeline, for of all competences of the 'independent operator'. The Russian side wanted to export high amounts for a long period and to have practical control over the Yamal pipeline (contrary to the idea of 'unbundling'). Although Polish negotiators never admitted it publicly, there is impression that the Russian side suggested that after completion of the Nord Stream (and South Stream) Yamal pipeline can be switched off. To avoid this perspective Polish government was ready to accept conditions proposed by the Russian side. A government representative admitted that the contract was 'in line with the 2nd EU energy packet' implying that was not in accordance with the famous 3 rd packet. It raised negative comments within Poland and, what is more important, negative reactions of the European Commission. EU Commissionaire for energy Günther Öttinger came to Poland and warned Polish government from making too big concessions to Gazprom and Russia. A process of renegotiation of the contract started, this time between three parties: Russia, Poland and the European Commission. Paradoxically, the EC, led by a German, tried to prevent too close cooperation between Poland and Russia while not long ago it was Poland who used to warn against too high dependence of Europe on Russia. Obviously, the change in the attitude of the Polish government is determined by the perspective of the Nord Stream. Without the Nord Stream Russian negotiators could not have blackmailed Poland. The gas contract with Russia is a matter of internal disputes in Poland: some oppose it arguing that it will extend Poland's dependence on Russian gas supply (until 2037), while others, notably the ministry of 
economy, defend it as securing supplies (until 2037) and functioning of the Yamal pipeline.'

Anyway, the contract makes that Poland will not need to buy Russian gas from Germany via Nord Stream. Thus, the contract weakens the position of Germany as 'gas hub' and as Russia's 'special partner'. If this reasoning is correct, it would mean that Russia has given up its long-term large-scale geopolitical plans to 'conquer' Europe with a little help from Germany.

Nabucco and South Stream. Nabucco is a European pipeline project to bring gas from the Caspian area (Azerbaijan, maybe also Turkmenistan, Iraq, Iran) to South-Eastern and Central Europe (Bulgaria, Romania, Hungary, Austria) via Georgia and Turkey, this way bypassing Russia. First the idea appeared in 2002 in an agreement between firms from Turkey, Bulgaria, Romania, Hungary and Austria. In 2004 Nabucco Gas Pipeline International GmbH was established by the mentioned companies. In 2009 German firm RWE joins the Nabucco Project as its shareholder. The same year Nabucco receives blessing of the Europen Union and of governments of countries concerned. Construction works should start in 2012 and be completed in 2015. ${ }^{10}$

The aim of Nabucco is to bring gas to Central and South-East European countries and to diminish their dependence on Russia. It can be considered as a response both to the growing demand for gas and to the more assertive attitude of Russia and fears that Russia can use gas supplies as a political weapon. It should be stressed that the process of materialising the Nabucco project is rather slow (at least ten years from the agreement to the supposed start of the construction works) when compared to the Nord Stream (5 years from the agreement to the start of the construction). This slowness can be attributed to the relatively weak position of the countries engaged and their companies in the European Union, doubts as to economic and political viability of the project and a counteraction of its rival - the South Stream project (below). Access of the German RWE in 2009 is of great importance. It seems to illustrate that some German politicians and businesspeople share doubts about Russia. It should be remembered that the decision of RWE to join Nabucco was taken after the RussianGeorgian war in August 2008 and after the January 2009 gas conflict between Russia and Ukraine.

South Stream can be analyzed both as an element in Russia's coordinated gas policy (together with the Nord Stream) and as a response to the Nabucco project. South Stream is a joint Russian (Gazprom) and Italian (ENI) venture established

\footnotetext{
${ }^{9}$ As The Economist puts it: 'Russia's new gas contract with Poland could tie that country to supplies from the east until 2037. Some Poles like this. Others, chiefly in the foreign ministry, think it could jeopardise the country's plans to develop its own reserves, and to build a terminal to import LNG'. See 'Europe's Gas Pipelines...' (2010).

${ }^{10}$ For more details see: www.nabucco-pipeline.com.
} 
in 2007 to transport Russian gas from Russia across the bottom of the Black Sea (thus bypassing Ukraine) to Bulgaria, Serbia, Hungary, Austria, Slovenia, northern Italy, with possible extension to France, and from Bulgaria to Greece and southern Italy. In 2009 the French EdF joint the company (receiving shares from ENI). Strong support from Italian government, and then access of France strengthens the position of the South Stream, and weakens that of Nabucco (Vetturini 2009).

As can be seen some countries: Bulgaria, Hungary and Austria belong to both projects. The problem is to what extent these are competitive and to what extent - complementary. It seems that at least governments and experts of the three countries consider them as complementary. Nevertheless there is strong lobbying for or against one or another. The most prominent persons engaged in this lobbying are two Germans: former chancellor Schröder very actively promoting the South Stream and discouraging Nabucco ${ }^{11}$ and former minister of foreign affairs in Schröder's cabinet, Joschka Fischer, supporting Nabucco. ${ }^{12}$

Apart from Nabucco and Southstream there are other projects, too, to bring gas to South-Eastern Europe. One of them is AGRI from Azerbaijan to Georgia, then after liquefying by tankers across the Black Sea to Romania and then after re-gasification by a pipeline to Hungary. As The Economist suggests 'AGRI will not carry as much gas as Nabucco's planned annual target of $38 \mathrm{bcm}$. But it is cheaper to build [...], and will save on Turkish transfer fees. Despite noisy political backing, AGRI's real role is probably to soften Turkey's negotiating stance.' ('Europe's Gas Pipelines...', 2010).

As to Poland, it backs the Nabucco project as it complements the aforementioned North-South European energy corridor (Kublik, 2011).

\section{CONCLUSION}

Energy security in general and natural gas supplies in particular have become a political issue in Europe, indeed a geopolitical game in which convergence of the general interests of gas suppliers, consumers and transit countries coexists with divergence of detailed interests concerning prices of gas, fees for transport, conditions of deliveries, routes of pipelines, ownership and control over pipelines, etc. It is also the game where common interests of Europe and Russia in

\footnotetext{
${ }^{11}$ For instance after Schröder's visit to Romania one Romanian journal called him 'Russia's advocate in Romania', another Romanian journal stated that 'Moscow spoke German' (thanks to Schröder) (Dobravie, 2008; 'Moscova vorbeşte...', 2008).

${ }^{12}$ See about the conflict between the two former politicians and now commercial lobbyists: 'Fischer keilt gegen Schröder...' (2009).
} 
the global system vie for priority with an idea of 'special relationships' of Russia with some EU countries, notably Germany and France and Italy, at detriment of countries of Central-Eastern Europe. Finally, it is a game where the centripetal forces of the European Union are confronted with centrifugal interests of its individual member states. In this game some actions, undertaken in specific economic and political conditions produce reactions in other circumstances changing the whole setting.

From the Polish point of view such an action was first of all the RussianGerman agreement on building the Nord Stream pipeline across the bottom of the Baltic Sea bypassing Poland. It was interpreted as dangerous for Polish national security. It imbued Polish leaders with a sense of distrust towards Germany and the EU which backed the project. As a reaction Polish government decided to build LNG terminal in the port of Świnoujście. This, in turn, has produced a new problem in the Polish-German relations, namely the above mentioned problem of blocking the access to the port by the Nord Stream pipeline in German territorial waters. Furthermore, having seen its negotiating stance weakened by the perspective of the Nord Stream and of switching off the vitally important Yamal pipeline, Polish government decided to accept conditions in the Polish-Russian gas contract in 2010 imposed by the Russian side that not entirely comply with EU energy policy and thus provoked tensions in relations between Polish government and the European Commission.

\section{REFERENCES}

BAUMANN, F. and SIMMERL, G. (2011), 'Between Conflict and Convergence: The EU Member States and the Quest for a Common External Energy Policy', CAP Discussion Paper, February, Research Group on European Affairs, www.cap.lmu.de/download/2011/CAP_ Paper-Baumann-Simmerl.pdf.

'Dlaczego Niemcy blokują rozwój terminalu LNG w Polsce' (Why Does Germany Block Development of LNG Terminal in Poland), (2010, August 6), www.mojeopinie.pl/dlaczego_ niemcy_blokuja_rozwoj_terminalu_lng_w_polsce,3,1281004437.

DOBRAVIE, M. (2008, November 13), 'Gerhard Schröder, avocatul Rusiei în România', Adevărul, Romania, www.adevarul.ro.

'Europe's Gas Pipelines. The Abominable Gas Man' (2010, October 16), The Economist.

'Fischer keilt gegen Schröder' (2009, September 28), Sueddeutsche.de, Germany, www.sueddeutsche.de.

HELM, D. (2007, September 3), 'The Russian Dimension of Europe's External Energy Policy', www.dieterhelm.co.uk/sites/default/files/Russian_dimension.pdf.

KUBLIK, A. (2011, February 1), 'Gazowa integracja Europy', Gazeta Wyborcza.

'Moscova vorbeşte nimeşte' (2008, November 13), Azi, Romania, www.azi.ro.

'Moskau nutzt seine Energie nicht als Waffe' (2009, October 8), Sueddeutsche.de, Germany.

'Russland ist ein zuverlässiger Partner' (2008, September 3), Sueddeutsche.de, Germany. 
'70 koncesji na gaz łupkowy' (70 Concessions for Shale Gas), (2010, August 24), http://biznes.interia.pl/news/70-koncesji-na-gaz-lupkowy, 1522030.

VARGA, T. (2008, November 18), Fogalmazzák az Északi Áramlat halálos itéletét, Kitekintő, Hungary, www.kitekinto.hu.

VENTURINI, F. (2009, October 20), 'Il pendolo verso Mosca', Corriere della Sera, Italy, www.corriere.it.

WYCISZKIEWICZ, E. (ed.), (2008), Geopolityka rurociqgów. Wspótzależność energetyczna a stosunki międzypaństwowe na obszarze postsowieckim, Warszawa: Polski Instytut Spraw Międzynarodowych.

www.nabucco-pipeline.com. 